ROCZNIKI FILOZOFICZNE

Volume LXIX, issue 3-2021

DOI: https://doi.org/10.18290/rf21693-8

RYSZARD MORDARSKI

\title{
BENEVOLENCE OR MERCY? THE PROBLEM WITH THE FIRST PREMISE OF THE HIDDENNESS ARGUMENT
}

The Hiddenness Argument formulated by J. L. Schellenberg is now considered a classic argument. We meet it in textbooks on the philosophy of religion, which means that it is discussed in academic courses for students of philosophy. Thanks to this, Schellenberg entered permanently into debates devoted to the arguments for the existence or non-existence of God. The literature on various aspects of this argument is already so extensive that it is even possible to design a scientific career focused on specialized analysis and criticism of this argument. ${ }^{1}$ Schellenberg himself facilitated the opportunity to discuss and criticize his argument, because after the original presentation in the book Divine Hiddenness and Human Reason, he published a more popular book in 2015, The Hiddenness Argument. Philosophy's New Challenge to Relief of God, in which he presented the argument in a more accessible way, and he showed some detailed issues from a slightly different point of view.

In this paper, however, I will not deal with a very sophisticated philosophical discussion that focuses on various, often very detailed, aspects of the Hiddenness Argument. Rather, I will deal with its main premise and try to criticize it from the perspective of Christian philosophy, or even more precisely from the perspective of Christian Catholicism. For Schellenberg assumes that his argument is so effective that it denies the existence of any God who is a personal

Ryszard Mordarski, PhD, Hab., Associate Professor at the Institute of Philosophy, Kazimierz Wielki University; correspondence address: ul. Dworcowa 13/46, 85-009 Bydgoszcz, Poland; e-mail: ryszard.mordarski@gmail.com; ORCID: https://orcid.org/0000-0003-2346-4572.

${ }^{1}$ Daniel Howard-SNyder and Paul K. Moser, eds., Divine Hiddenness: New Essays (Cambridge: CUP, 1993); Adam GrEEN and Eleonore STUMP, eds., Hiddenness Divinity and Religious Belief. New Perspectives (Cambridge: CUP, 2015). 
being. Therefore, it is worth considering whether it undermines the understanding of God that is presented in Catholic doctrine. For if it turns out that the Hiddenness Argument is not entirely accurate in relation to Catholic doctrine, then one might conclude that it may not be accurate in criticizing other theistic approaches as well.

In one of the last versions, the Hiddenness Argument is formulated as follows: ${ }^{2}$

(1) If a perfectly loving God exists, then there exists a God who is always open to a personal relationship with any finite person.

(2) If there exists a God who is always open to a personal relationship with any finite person, then no finite person is ever nonresistantly in a state of nonbelief in relation to the proposition that God exists.

(3) If a perfectly loving God exists, then no finite person is ever nonresistantly in a state of nonbelief in relation to the proposition that God exists (from 1 and 2).

(4) Some finite persons are or have been nonresistantly in a state of nonbelief in relation to the proposition that God exists.

(5) No perfectly loving God exists (from 3 and 4).

(6) If no perfectly loving God exists, then God does not exist.

(7) God does not exist (from 5 and 6).

The strength of this argument lies in the accuracy of the deductive reasoning. This means that, if the premises of an argument are correct, the conclusion must necessarily be true. The key to this argument is the first premise. It says that if there is a God, it must be a personal being endowed with the attribute of perfect love. God would have to be perfectly loving. So, the question: Must a God be Loving? is the most important question in this argument, and-as Schellenberg says - "everything hangs on it." 3 Most theists consider this premise correct and intuitively true, so they do not pay much attention to it. However, establishing exactly what God's love is all about seems to be the most important thing for the correctness of the whole argument. Moreover, it seems that a careful examination of the first premise of Schellenberg's argument can show that it is based on penumbra; at first glance it is obvious, but on closer examination of how we should understand the attribute of God's love, it turns out that this premise is one-sided and incomplete, and perhaps even completely wrong. Therefore, in this paper we will argue that although

2 J. L. SChellenberg, The Hiddenness Argument: Philosophy's New Challenge to Belief in God (Oxford: OUP, 2015), 103.

${ }^{3}$ Ibid., 89. 
the thesis that God always loves all human beings and always tries to establish a personal relationship with them is true, for an adequate understanding of this relationship, classic vertical models are better than Schellenberg's horizontal models of love. This may suggest that the so-called benevolent theism advocated by Schellenberg should be replaced by a more adequate approach, expressed by merciful theism or theism of mercy. Therefore, if we manage to weaken the first premise or show its inadequacy, then we will have to recognize the conclusion of the Hiddenness Argument as false.

\section{LOVE AS BENEVOLENCE}

In order to answer the question of what it means for God to enter into a relationship of love with human beings, Schellenberg wants to establish at the outset which God is referred to in his argument. He points out that among the various attributes we can attribute to God, such as omnipotence, omniscience, and absolute goodness, one can also indicate perfect love. But what is God's love, and what does it mean exactly that God loves us? Schellenberg points out that the basic quality that comes to mind in this context is "benevolence." When we say that God loves us, we mean that God is kind to us, cares for us, and wants our good. It therefore affirms that God's love or benevolence towards human beings is what philosophy has traditionally conveyed through the term agape, which means love as a gift, as opposed to the term eros, which means love as a desire and characterized imperfect human love.

According to Schellenberg, apart from understanding God's love as benevolence, there is another extremely important, though somewhat forgotten feature of love; love is the pursuit of a personal relationship with another person. Since we accept that one of God's attributes is perfect love, it follows that God seeks to establish a relationship with all the intelligent creatures he loves. If we want to adequately explain the fact that "God loves us," then we should assume that "God is looking for a personal relationship with us." Therefore, Schellenberg writes: "I am claiming that God, if loving, seeks explicit, reciprocal relationship with us, involving not only such things as Divine guidance, support, and forgiveness, but also human trust, obedience, and worship." ${ }^{5}$ This indicates that love has the quality of sharing. If someone loves someone else,

\footnotetext{
${ }^{4}$ J. L. Schellenberg, Divine Hiddenness and Human Freedom (Ithaca, NY: Cornell University Press, 1993), 17.

${ }^{5}$ Ibid., 18.
} 
he wants to fully commit to his good, promote his happiness and fulfillment, and participate in his joy. This is the relationship of love between people, which is the highest ideal of a personal relationship of self-giving or giving oneself completely to the other. Therefore, the model of human love can best be used as an analogy to divine love. "The best human love could serve as an analogy of Divine love, and human love at its best clearly involves reciprocity and mutuality." And human love is most fully realized in the relationship of parents towards their children. In Schellenberg's opinion, the model of parental love best reflects the relationship of God's love towards human beings. "If God is a person and God has brought into the Word finite persons capable of relationship with God and indeed fulfilled only by it, then something very like the parent-child relation exists between God and finite persons." ${ }^{77}$ Since God is perfectly benevolent, then, like parent, He should commit all possible resources to human beings to establish the most intimate personal relationship with them. ${ }^{8}$

In principle, we could agree with that, although some doubts may arise at this point. Schellenberg seems to understand God's love, not so much in metaphysical contexts (as a transcendent attribute of God), but above all in contemporary contexts that can sometimes provide caricatured images of love. Hence, Schellenberg speaks of God's love in the following contexts:

- existential (in terms of interpersonal relationships),

- emotional (in terms of positive or good mental relationships),

- utilitarian (in terms of ethical goods and experimental benefits),

- sociological (in terms of partnerships),

- political (in terms of democratic and feminist patterns provided by contemporary liberal culture and politics).

One can therefore get the impression that Schellenberg wants to reject the traditional concept of love of God and replace it with some modern, horizontal, partnership, and feminist model based on emotions. ${ }^{9}$ That is why he so stubbornly assumes that the image of God's true love for human beings must be close to the partnership pattern. Such an image is popular in today's liberal and democratic societies. It shows the love of parents towards their children as unconditional devotion, which is founded mainly in the emotional sphere

\footnotetext{
${ }^{6}$ Ibid., 18.

${ }^{7}$ SChellenberg, The Hiddenness Argument, 99.

${ }^{8}$ SCHEllenBerg, Divine Hiddenness, 18.

9 ReA, "Hiddenness and Transcendence," in GreEn and STUMP, Hiddenness Divinity and Religious Belief; REA, The Hiddenness of God (Oxford: OUP, 2018).
} 
and devoid of context of reference to objective good. In this approach, since God loves us, he will unconditionally strive for a relationship with us. The relationship of God's love must be directed to every person without exception, because perfect love is not limited by anything and does not favor anyone. God's love should be realized in the task scheme: "If God is loving perfectly, he must love us." On the part of human being, this account is shown to be completely passive and to some extent infantile. It is based on the belief that God's love is simply due to us. Since God is a loving being, He will always come to us, even when we ourselves fall into a culpable situation and turn away from Him. Is this the complete truth about the Christian understanding of God's love for human beings? Do the analogies used by Schellenberg adequately capture one of the deepest and most intimate relations between God and humans? Has it really been held in the Christian tradition that God desires a relationship with us at all costs and allows us to participate in his life completely unconditionally?

\section{A FORGOTTEN SOURCE OF THE CHRISTIAN IDEA OF LOVE}

In order to use the adequately human analogy of love, we must remember that the very concept of love in relation to human beings has a very long and very varied tradition in the history of Western civilization. Western culture has developed numerous and sometimes even conflicting opinions and patterns about love. ${ }^{10}$ Love is often perceived too narrowly today. One-sided emphasis is on psychological, sociological, and even physiological aspects, while ethical, metaphysical and theological aspects are relegated from the background or completely ignored. Thus, a descriptive rather than a normative understanding of love dominates. This inevitably leads to the fact that we are confronted with many different, often contradictory understandings of love. The question then arises which of the contemporary models of love should be considered as the most representative for an adequate description of the reality of God's love? Is there any good and useful method to purify the idea of love in such a way that the most representative features of God's love can be distinguished?

It seems that the best method to reconstruct the Christian concept of God's love will be to return to the ancient Greek and biblical historical sources that formed the two most creative models of love and incorporated them into the

${ }^{10}$ Denis de Rougemont, L'Amour et l'Occident (Paris: Librairie Plon, 1956). 
bloodstream of Western culture. ${ }^{11}$ However, it should be remembered that the Greek ideas about love, thematized in the Platonic concept of eros, and the wonderful idea of love as a gratuitous gift, presented in the biblical idea of agape, were completed in medieval scholasticism by the tradition of Christian mystical love, which formed the unique via christianitas in the understanding of God's love.

Already in the Platonic model of love as a desire, there are successive stages on the way to full love, which can be described in today's language as a transition from the sensual, through the emotional, and then the ethical, to the metaphysical. At each of these stages, there is a temptation to stop the eros, get saturated with a specific act of love, and eventually exhaustion or weariness. Love then ceases to be the basic act of spiritual dynamism contributing to development and growth, but on the contrary burns out and degenerates in selffulfillment. Moreover, Platonic eros is summarized in the desire for something that is lacking for the lover and what the loved has (beauty and the good associated with it), and therefore the result of this love is the improvement of the lover himself (regardless of the mutual relationship). ${ }^{12}$ The danger inherent in the mindless power of eros was already noticed by Aristotle and therefore he opposed it with a friendship motivated by the desire for ethical good for a friend. Full relationship in love or friendship consists in mutual recognition of the absolute ethical value of both lovers. For Aristotle, however, such a mutual relation cannot exist in a human-God relationship because of the enormous distance between human virtue and God's goodness. ${ }^{13}$

Contrary to the nature of the dynamics of the Greek eros, the biblical agape is a patient and gentle love that has its source only in God. The New Testament in the Pauline "Hymn to Love" from chapter 13 of the First Letter to the Corinthians outlines mainly the ethical aspect of love, while in the writings of St. John, we find an important complement to the image of love with a metaphysical aspect. St. John points to love as the most important attribute of God and, trying to briefly characterize who God is, says that "God is love..." (1 John 4:16). Man can realize agape love only when he is united with God, because every act of love consists in participation in relation to the very source of love, which is God. Here we see clearly all the difference between agape love and

\footnotetext{
${ }^{11}$ Vincent Brummer, The Model of Love: A Study in Philosophical Theology (New York: CUP, 1993).

${ }^{12}$ Gene OutKA, Agape. An Ethical Analysis (New Haven and London: Yale University Press, 1972).

${ }^{13}$ Let us add that Aristotle, unlike Schellenberg, pointed out that kindness is the beginning of friendship, but it does not exhaust it and it is appropriate not only for it (ARISTOTLE, Nicomachean Ethics, trans. Christopher Rowe (Oxford: OUP, 2002), 1159a).
} 
eros love. Agape is a top-down love; it comes from God, breaks the selfishness of man and continues to spread over the entire world of creatures. Eros, on the other hand, is a bottom-up love; it begins with the sensual, then transforms human feelings and finally leads us to the highest regions of the spirit. Agape is anchored in God and shows human affairs in a supernatural perspective; eros, on the other hand, is a natural force dependent on the value of your object. Agape is essentially directed towards the other, eros focuses mainly on itself and only incidentally leads to deeper interpersonal relationships. ${ }^{14}$

Looking at the further development of the idea of love in Western culture, we can easily see how the classical and biblical model of love interpenetrated, opposed each other, or one of them tried to dominate the full understanding of love. When we try to group these models, we have either a synthesis and complementarity of eros and agape, or dualistic and alternative approaches, or a reduction of one aspect to another, on the one hand in the ideals of chivalrous and romantic love, and on the other hand in naturalistic concepts, bringing love down to the usual erotic drive. However, the dominant belief in Christianity was that eros was inspired by nature and agape was inspired by grace. In Catholic thought, however, eros was not viewed in a purely negative way, seeing in eros the necessary dynamism and vitality that can be used in the service of agape. Agape itself was seen as a necessary aid to eros, providing personal depth and opening man to transcendent perspectives.

The first attempt to develop a specifically Christian concept of love that would result from the fusion of eros and agape was made by St. Augustine. His idea of caritas love was characterized by an attitude of readiness to come to the aid of anyone in need. It can be said that this is the idea closest to what Schellenberg describes with the word "benevolence." Augustine wanted to work out a modus vivendi between two lifestyles: vita activa and vita contemplativa. It seems that this led to the emergence of a particular Christian type of love-mystical love, which would be, in a way, the third way between the human eros and God's agape approaches to love. This third model seemed to meet the conditions for understanding what the best analogy is for understanding God's love. On the one hand, he described human love (although different from the eros perspective), and on the other hand, he showed what God's love really is (while avoiding the difficulties contained in the transcendent model of agape love).

It can be said that the model of mystical love was developed in two stages: the first were scholastic concepts (Saint Bernard of Clairvaux, William

\footnotetext{
${ }^{14}$ Anders Nygren, Agape and Eros, trans. Philip S. Watson (London: S.P.C.K., 1957).
} 
of Saint-Thierry), and the second was the Spanish mysticism that was taking shape at the threshold of modernity (Saint John of the Cross and Saint Teresa from Avila). The scheme of the mystical conception begins with the idea of a loving God, to whose love man responds with the desire and striving for unity, which is realized by harmonizing the human will with the will of God. It is only as a consequence of the mystical union that God grants man supernatural gifts of grace which are the fruit of agape love. The question immediately arises whether in the relationship of love between God and man, God is the active side of love, and man is only waiting passively for this love to be directed to him, in order to respond to it? Or does the cooperation of love between God and man consist in the fact that despite the fact that God is always the first to offer love, however, without man's active pursuit and search for this love, the mutual relationship of love will never be fully realized, and it may not even be experienced by man? In a word, we ask whether in the relationship of love between God and man, only God is involved, or must both God and man be involved in order for God's love to be experienced by man?

Answering this question, the medieval monk Bernard of Clairvaux in his treatise On Loving God formulates the Cistercian doctrine of the mystical love. He distinguishes four stages on the way to God's love, analogous to the four stages of the realization of love in the Platonic model: ${ }^{15}$

1. man loves himself for self's sake,

2. man loves God for self's sake,

3. man loves God for God's sake,

4. man loves himself for God's sake.

When we look at the relationship of love between man and God in the bottom-up scheme, we must recognize, following Bernard, that man is primarily obliged to love God. But it follows that the deepest truth about God is that $\mathrm{He}$ does not so much possess love as $\mathrm{He}$ is, in his infinite nature, the immeasurable source of love. Therefore, first, no one is more loving than God; and second, no one can love anything but God more to their own benefit. But at St. Bernard's bottom-up diagram is supplemented with the top-down diagram. Man alone is not able to adequately assess and comprehend God's infinite love, therefore God himself helps man to transform selfish and sensual love and lead him through successive stages of love. First, man begins to love himself with pure love (stage 1), in which he returns to the true image and likeness of God (stage 2). But true reciprocity between the Creator and creation is possible when both

\footnotetext{
${ }^{15}$ Bernard, On Loving God (Kalamazoo, MI: Cistercian Publications, 1995).
} 
parties give their best of themselves to participate in the uniting experience of love. Only then can the infinite distance between the Creator and the creature disappear. A community emerges in which nothing divides them, because they have kept nothing for themselves. Love is the only plane where the relationship between God and man becomes equal and can lead to true communion (stage 3). The climax of contemplative knowledge of God is plunging into God through ecstasy (stage 4). On this highest level, a person can experience how the will of God is completely fulfilled in him. It is true that earthly difficulties do not allow us to fully rest in God, so it will be possible only after death, when the human soul is perfectly united with God.

The Spanish mystic of love in the 16th century described the relationship between the love of God and man in a similar way. Following the path of the Platonic eros, the Carmelite writers recommended the total purification of the sensual human nature, by detaching oneself from all created things and renouncing all desires and imperfections, in order for humility to completely harmonize one's will with God's will. Love for God begins to be realized in the moment of a radical transformation of the whole life, which consists in total emptiness and detachment from everything that is earthly, in order to turn fully to God as the object of love. But most importantly, unlike the path of eros, man is accompanied on the path of mystical love by the spiritual dryness and suffering that St. John of the Cross calls "dark night." Thus, we see that this path is a path of specific spiritual exercises, on which, through prayer and contemplation, all egoism is burned out in man, which obscures and hinders communion with God. It is a specific pedagogy of God, educating man to the full experience of God's love. In the experience of love, it shows a farther horizon, an elusive depth that opens a person to something more than just the object of our loving reference. So, if we recognize mystical love as the broadest horizon of love, then we must accept that only a person's transformation under the influence of God's love allows him to fully understand what love really is. ${ }^{16}$

Someone will say now that even if this is the full truth about love, the depths of mystical love are only available to the few people who have devoted themselves fully to God. But it seems untrue: the call to contemplation is a call to choose such an option of life in which man seeks God and tries to integrate his will with God's will. It is therefore a call to all rational creatures, and the promise for fulfilling this call is precisely to experience what deep and sincere love is. But even if the heights of mystical love were reserved only for a few,

\footnotetext{
${ }^{16}$ Kieran Kavanaugh, ed., John of the Cross: Doctor of Light and Love (New York: Crossroad Publishing, 1999).
} 
the Christian has a duty to listen to the voice of those who have reached these heights in the most perfect way, because perhaps they have something very important to tell us about what God's love is.

\section{LOVE AS AN ATTRIBUTE OF GOD}

A theist may, however, ask not so much what God's love is, but rather how it is actually realized in relation to people. Are we able to somehow understand and describe it, or are we reliant only on experiencing it and perhaps after long preparation, which only a few are capable of? Since love is one of the fundamental attributes for understanding the nature of God, by focusing on the analysis of love, we should get the best way not only to understand who God is, but also how He works with human beings. Moreover, if God's love is infinite, then should He not love all people? Schellenberg writes: "If God is perfectly loving, He must give himself wholly to his creation, and to his whole creation." ${ }^{17}$ Even if not all people are capable of a full relationship with God, $\mathrm{He}$ should not favor anyone, but rather help those who are the least perfect. So, it seems Schellenberg is right when he writes: "If God is perfectly loving and creates an individual with a capacity for such relationship, he must surely seek to help him to exercise it." ${ }^{18}$ Moreover, since a relationship with God brings many existential, moral, religious and spiritual benefits to human beings, then "we might expect a perfectly loving God, concerned for our well-being, to make such relationship possible for us." 19 And if we find that love is a relationship valid not only for its own sake but also for our sake, should God not be under an obligation to bring about to such a relationship. Schellenberg argues that if God did not make all the effort He could to seek to establish a relationship with every human being, it might be thought that $\mathrm{He}$ is not a loving being: "I would suggest that there is indeed reason to suppose that a being who did not seek to relate himself to us explicitly in his life-who elected to remain elusive, distant, hidden, even in the absence of any culpable activity on our part-would not properly be viewed as perfectly loving." 20

However, the basic difficulty with this statement may appear already at the moment of defining the nature of God's love towards humans. What does it

\footnotetext{
${ }^{17}$ SCHELLENBERG, Divine Hiddenness, 24.

${ }^{18}$ Ibid., 25

${ }^{19}$ Ibid., 21.

${ }^{20}$ Ibid., 28-29.
} 
mean that God is a perfectly loving being? What does it even mean for God to love human beings? For we cannot fall into excessive anthropomorphization and adopt the analogy of romantic or democratic-partner love too literally. Since God is transcendent, the comparison and parallel between divine and human love can be misleading and the pattern of love of human parents may be totally inadequate for understanding God's love. The question then arises, can we say anything positive about God's love when we speak of human love? It seems that even if love is the feature that best characterizes the nature of God, since God is not a man, not all the implications of love regarding human relationships can be unequivocally applied to Him. We must remember that such attributes of God as simplicity, necessity, immutability, eternity, and transcendence do not apply to humans at all. This points to limitations that may apply to God also in ascribing to Him the quality of love. This leads to the question of what exactly it means to call God the God of love, and how does God's love differ from human love. Does the difference between God's love and human love come down only - as Schellenberg suggests - to the degree of love's intensity? ${ }^{21}$ Does the love of God who is the most perfect person possible, come down to loving the most perfectly of all humans? And what exactly does it mean to be a person who is perfectly loving?

Classical theism indicated a completely different understanding of the attribute of God's love than the relation of expectation proposed by Schellenberg, which summed up in the requirement for God: if you love me, you must establish a relationship with me. For Aquinas, the love of God is one, eternal, simple and unchanging act of will, consisting in the inclination for good for all people. The simplicity and immutability of God means that God's love is associated with will, not with feelings. Therefore, God loves without feeling, which does not mean imperfection, but precisely the perfection and immutability of love. It also does not mean any stagnation or lack of dynamics in God's love; God's love is active, not passive. Aquinas says that "God loves everything that exists. Yet not as we love.... The love of God infuses and creates goodness. But God does not love like we do... God's love fills things with goodness and creates it in them." 22 Since God wants things to exist, $\mathrm{He}$ wants good for what exists, and if He wants good, He loves everything that exists. Thus, Thomas emphasizes the metaphysical nature of God's love, which funds the existence of his creatures and bestows them with goodness.

\footnotetext{
${ }^{21}$ SCHELLENBERG, The Hiddenness Argument, 99.
}

${ }^{22}$ Aquinas, Summa Theologica, I q. 20 a. 2. 
Schellenberg opposes the metaphysical understanding of God's love, pointing out that it is a legacy of ancient Greek ideas about immutability that cannot be maintained today. He also believes that refusing God's love of an emotional character is a patriarchal and anti-feminist view of the value of emotions. These statements return to the error of emotional and psychological perception of love presented by Schellenberg. But even if we do not want to fully acknowledge Aquinas' approach to love of God, it seems we can accept its highly moral character. For Aquinas, the ethical nature of love includes two factors: it is a kind relationship to the other person, but it is also a relationship that wants good for him there is no true love when we accept the evil that the other person chooses just because that we love him. If love were just a friendly relationship to another, then it would assume that we accept whatever the other person wants and chooses, whether it is good or bad. So, apart from the relationship to another person, an attitude towards good is also important in love. Love is therefore not the mere desire for a good relationship of personal reciprocity, regardless of the objective good, but the desire for good for another human being. A relationship of love occurs when we make it easier for another person to achieve the good that she wants. Therefore, the relationship of love that can be established between the infinite and perfectly good God and the finite and sinful human person can only be realized on the plane of objective good. This means that the horizontal model of love based on benevolence should be replaced or complemented by a vertical model based on good, which includes forgiveness and reconciliation coming from God.

\section{LOVE AS MERCY}

Mercy seems to be a candidate for this kind of good coming from God, which at the same time has biblical sources. This was recalled in the 20th century by the Polish nun Faustina Kowalska, who experienced mystical revelations of Christ in the period between the First and Second World Wars. They were described in plain and poignant language in her Diary. ${ }^{23}$ They focus on conveying to people the basic truth that mercy is at the heart of God's love. Inspired by this message, Pope John Paul II wrote in the 1980 encyclical Dives et Misericordia. The Polish pope points out that we should see God as a Father rich in mercy, Who is - as Saint Paul says - "The merciful Father, the God

\footnotetext{
${ }^{23}$ Faustina Maria KowALSKA, Diary. Divine Mercy in My Soul, 3rd ed. (Stockbridge, MA: Marian Press, 2003).
} 
from whom all help comes" (2 Cor. $1 ; 3)$. Mercy is the most important manifestation of God's love for human beings: "For mercy is an indispensable dimension of love; it is as it were love's second name and, at the same time, the specific manner in which love is revealed and effected." ${ }^{24}$ The Pope, referring to the story about the prodigal son, reminds us that the broken relationship of love between father and son is restored when the son recognizes his recklessness resulting from leaving his family home and decides to return and ask his father for forgiveness: "I shall get up and go to my father and I shall say to him, 'Father, I have sinned against heaven and against you. I no longer deserve to be called your son; treat me as you would treat one of your hired workers" (Luke 15:18-19). The father is expecting a son; he is ready to accept him immediately and forgive him for everything, because his paternal love is faithful and unchanging. The father did not withdraw the love he had for his son, but waited patiently, and to a certain extent, hidden until his son would be transformed personally and would open up again to his father's love and humbly acknowledge his guilt. The love relationship is restored when the son finds a lost good that he shared with his father. On the part of the father, merciful and forgiving love can be completed, and on the part of the son, a love of conversion and a request for forgiveness can be completed.

John Paul II refers to the father-son relationship, but if someone is offended by the archaic biblical language, let us refer to a contemporary example. Imagine a mother whose son was a drug dealer, jailed for his crime but showing no remorse. He argues that drug business is his way of realizing freedom and enabling others to fully develop their personality. Realizing his immoral will to power, he fully experiences his humanity and experiences maximum satisfaction. Now let us ask how will a mother's love for such a son be realized? Will it be a fully mutual relationship between two people? A mother loves her child but does not share his immoral desires. Hence, her love will be subject to deep frustration and unfulfilling. The relationship that may exist between her and her child will be a desire for her son to change, even as he himself assures her that he is completely fulfilled and perfectly happy. Only when they are united by the common good - respect for the health and life of other people - that is, only when her son understands that drug dealing was wrong, will their relationship develop anew. They will be joined again by the regained and shared good that they want for each other. A mutual interpersonal relationship is complete and mutually edifying only when both sides bestow on each other

${ }^{24}$ John Paul II, Dives et Misericordia, in Pope John Paul II. Encyclicals (Trivandrum, India: Carmel International Publishing House, 2005), 8. 
the common good they want for each other. The happiness of such a relationship is possible only on the basis of objectively experienced good.

This example is not perfect: we must remember that God does not love others, but He is love, which means that His love is one simple act, eternal and unchanging, which covers the whole of creation, from its beginning to its end, and so it also covers the entire life of every human being, from birth to death. This means that from God's side the relationship of love is permanent and unchanging. If at some point in our lives (or in our entire life so far) we do not experience it or we experience it indistinctly, it only means a problem on the part of a human being. If the lack of this relationship is the result of closing ourselves on God and pursuing our selfish path of freedom, for which we do not even feel any remorse, then we must recognize that God is not to blame for it. To re-establish a deep and personal relationship with God, it is enough to recognize that $\mathrm{He}$ is the source of all moral good for every human being and a metaphysical condition for ultimate fulfillment and happiness. We can therefore agree with what Paul Moser suggests that God's love is a "peaceful offer" that does not force but invites us to cooperate and participate in the project of moral and spiritual improvement of man. It is a self-sacrificing love that is primarily redemptive and redeeming. ${ }^{25}$

The fact that modern man does not feel and does not experience God's love may result from the complete infantilization and trivialization of the very concept of love. We cannot expect God to distribute His love for people automatically and against their will. This does not mean that God's love does not work on people, but that it is an act so exceptional that it requires special preparation from humans so that they can fully accept it. Perhaps this is also the reason for the hiddenness of God, who protects His creation from violent and direct encounters with Himself. It seems that one needs to prepare for a deep and serious relationship of love with God in the process of humble conversion. If we accept this, then we must agree that the benevolent theism approach is too superficial and should be replaced by the deeper approach represented by the merciful theism or theism of mercy, which more adequately describes the essential and profound aspects of God's love.

${ }^{25}$ Paul K. Moser, "Divine Hiddenness and Self-Sacrifice," in GreEN and STUMP, Hiddenness Divinity and Religious Belief. 


\section{CONCLUSION}

Finally, let us ask what the implications of the above conception of God's love are for the first premise of the Hiddenness Argument. First, God can love every human being even though they may not know it. Second, God's love is not only an act of benevolence, but must be completed by the perspective of merciful love, which most fully reflects the essence of God's love for humans. Third, to maintain the understanding of God as a transcendent being in relation to the world, we must show His relationship to human beings in a vertical model, not a horizontal model, which further emphasizes the idea of merciful love at the expense of the idea of benevolence. Fourth, merciful love is an act of the highest subtlety and a delicacy that requires an active human response and does not exclude the hiddenness of God from those human beings who are not prepared to fruitfully accept this act. And finally, if we use the analogy of human love to describe God's love, then using the model of democratic partnerships between parents and children ruling in the liberal-democratic world is not the most appropriate reference.

If the above argument is correct, then it seems that the first premise of the Hiddenness Argument, if not even completely false, is quite weakly grounded and requires better clarification. It may be argued that this clarification should consist in complementing the theism of benevolence with the theism of mercy. However, when we do this, serious doubts will arise whether the Hiddenness Argument will still be conclusive?

\section{BIBLIOGRAPHY}

AQUINAS, Thomas. Summa Theologica. Translated by the English Dominican Fathers. Vol. 1, 1a QQ. 1-119. Notre Dame, IN: Ave Maria Press, 2000.

ARISTOTLE. Nicomachean Ethics. Translation and historical introduction by Christopher Rowe, philosophical introduction and commentary by Sarah Broadie. Oxford: Oxford University Press, 2002.

Bernard. On Loving God. Cistercian Fathers Series 13B. Analytical commentary by Emero Stiegman. Kalamazoo, MI: Cistercian Publications, 1995.

Brummer, Vincent. The Model of Love: A Study in Philosophical Theology. New York: Cambridge University Press, 1993.

Green, Adam, and Eleonore STuMP, eds. Hiddenness Divinity and Religious Belief. New Perspectives. Cambridge University Press, 2015.

Howard-Snyder, Daniel, and Paul K. Moser, eds. Divine Hiddenness: New Essays. Cambridge: Cambridge University Press, 2002. 
John Paul II. Dives et Misericordia. In Pope John Paul II. Encyclicals. Trivandrum, India: Carmel International Publishing House, 2005.

Kavanaugh, Kieran, ed. John of the Cross: Doctor of Light and Love. New York: Crossroad Publishing, 1999.

KowAlSKA, Faustina Maria. Diary. Divine Mercy in My Soul. 3rd ed. Stockbridge, MA: Marian Press, 2003.

Moser, Paul K. "Divine Hiddenness and Self-Sacrifice." In GREEN and STUMP, Hiddenness Divinity and Religious Belief, 71-88.

Nygren, Anders. Agape and Eros. Translated by Philip S. Watson. London: S.P.C.K., 1957.

OutKA, Gene. Agape. An Ethical Analysis. New Haven and London: Yale University Press, 1972.

REA, Michael C. "Hiddenness and Transcendence." In GreEN and STUMP, Hiddenness Divinity and Religious Belief, 210-25.

REA, Michael C. The Hiddenness of God. Oxford: Oxford University Press, 2018.

Rougemont de, Denis. L'Amour et l'Occident. Paris: Librairie Plon, 1956.

Schellenberg, J. L. Divine Hiddenness and Human Freedom. Ithaca, NY: Cornell University Press, 1993.

Schellenberg, J. L. The Hiddenness Argument: Philosophy's New Challenge to Belief in God. Oxford: Oxford University Press, 2015.

\author{
BENEVOLENCE OR MERCY? THE PROBLEM WITH \\ THE FIRST PREMISE OF THE HIDDENNESS ARGUMENT
}

$\mathrm{S} \mathrm{u} \mathrm{m} \mathrm{m} \mathrm{a} \mathrm{r} \mathrm{y}$

The first premise of J. L. Schellenberg's Hiddenness Argument equates God's love with a positive relationship to human beings. To illustrate this relationship, the human model of parental love is used, based on the standards of the modern American liberal world, not on the biblical standard. As a result, we attribute to God a narrowly understood horizontal relationship towards people, which is completely alien to the understanding of love developed in the Christian tradition. When we refer to the classical theism that recognized love as the central attribute of God, we will see that it should be understood in a vertical model, consisting in the offering of good and mercy. This understanding undermines the benevolent theism and replaces it with the merciful theism or theism of mercy. Ultimately, this makes the first premise of the Hiddenness Argument very questionable and the whole argument calls for a significant revision.

Keywords: Hiddenness Argument; God's love; attributes of God; models of Christian love; benevolent theism; merciful theism, J. L. Schellenberg. 


\section{DOBROCZYNNOŚĆ CZY MIŁOSIERDZIE? \\ PROBLEM PIERWSZEJ PRZESŁANKI ARGUMENTU Z UKRYTOŚCI}

\section{Stres z c z e n i e}

Pierwsza przesłanka J. L. Schellenberga argumentu z ukrytości zrównuje miłość Boga z pozytywnym stosunkiem do człowieka. Aby zilustrować tę relację, posłużono się ludzkim modelem miłości rodzicielskiej, opartym na standardach współczesnego amerykańskiego liberalnego świata, a nie na standardach biblijnych. W rezultacie przypisujemy Bogu wąsko rozumiany horyzontalny stosunek do ludzi, który jest zupełnie obcy pojmowaniu miłości wypracowanemu w tradycji chrześcijańskiej. Kiedy odwołamy się do klasycznego teizmu, który uznawał miłość za centralny przymiot Boga, zobaczymy, że należy ją rozumieć w modelu wertykalnym, polegającym na ofiarowaniu dobra i miłosierdzia (łaski). Takie rozumienie podważa teizm dobroczynności i zastępuje go teizmem miłosierdzia (łaski). Dzięki temu okazuje się, że pierwsza przesłanka argumentu z ukrytości jest bardzo wątpliwa, a cały argument wymaga znaczącej rewizji.

Słowa kluczowe: argument z ukrytości; miłość Boga; atrybuty Boga; modele chrześcijańskiej miłości; teizm dobroczynności; teizm miłosierdzia; J. L. Schellenberg. 